\title{
Original paper \\ Effect of natural irradiation in fluorites: possible implications for nuclear waste management?
}

\author{
Vojtěch VLČEK ${ }^{1,2^{*}}$, Roman SKÁLA ${ }^{1,3}$, Viktor GOLIÁŠ', Jan DRAHOKOUPIL ${ }^{4,5}$, Jakub ČíŽEK ${ }^{6}$ \\ Ladislav STRNAD ${ }^{7}$, Jana EDEROVÁ ${ }^{8}$
}

${ }^{1}$ Institute of Geochemistry, Mineralogy and Mineral Resources, Faculty of Science, Charles University in Prague, Albertov 6, 12843 Prague 2, Czech Republic; email:vojtech.vlcek@gmail.com

${ }^{2}$ Bayerisches Geoinstitut, Universität Bayreuth, D-95440 Bayreuth, Germany

${ }^{3}$ Institute of Geology, AS CR, v.v.i., Rozvojová 269, 16500 Prague 6, Czech Republic

${ }^{4}$ Institute of Physics, AS CR, v.v.i, Na Slovance 2, 18221 Prague 8, Czech Republic

${ }_{5}^{5}$ Faculty of Nuclear Sciences and Physical Engineering, Czech Technical University, Břehová 7, 11519 Prague 1, Czech Republic

${ }^{6}$ Department of Low Temperature Physics, Faculty of Mathematics and Physics, Charles University in Prague, V Holešovičkách 2, 18000 Prague 8, Czech Republic

${ }^{7}$ Laboratories of the Geological Institutes, Faculty of Science, Charles University in Prague, Albertov 6, 12843 Prague 2, Czech Republic

${ }^{8}$ Laboratory of Thermal Analysis, Institute of Chemical Technology, Technická 3, 16628 Prague 6, Czech Republic

* Corresponding author

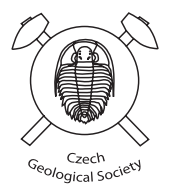

Samples of naturally irradiated fluorite have been analyzed by means of X-ray powder diffraction analysis (XRPD), differential scanning calorimetry (DSC) and laser ablation inductively coupled plasma mass spectrometry (LA-ICP-MS). The diffraction patterns of all irradiated samples show peak broadening caused by micro-strain, which was evaluated by Williamson-Hall method, and an increase in the unit cell parameter. The DSC analysis showed an exothermic peak at $273^{\circ} \mathrm{C}$ corresponding to enthalpy change about $16 \mathrm{~kJ} \cdot \mathrm{mol}^{-1}$. This value is an order of magnitude higher than calculated change due to unit cell volume increase that is only $2 \mathrm{~kJ} \cdot \mathrm{mol}^{-1}$. The LA-ICP-MS did not show any significant substitutions, which might account for observed unit-cell parameter increase. The results have shown that high radiation doses lead to formation of defect clusters.

Keywords: fluorite, irradiation, X-ray diffraction, differential scanning calorimetry, defects, real structure Received: 27 September 2011; accepted: 27 February 2012; handling editor: F. Laufek

\section{Introduction}

Simple halides are generally important for nuclear waste management; the widespread examples represent spent-fuel container repositories in geologic formations including mainly evaporate sequences. Based on studies of experimentally irradiated samples, fluorite and substances with fluorite-based structures have been repeatedly expected to represent materials suitable for nuclear waste management (Chadderton 2003). The suitability of substances with fluorite structure type for this purpose stems from the fact that they are isotypic with nuclear fuel itself ( $\mathrm{UO}_{2}$ pellets). These studies, though applying radiation doses of variable intensity, cannot account for time factor. Consequently, the samples of fluorite that underwent a natural irradiation lasting millions of years represent the only material suitable for investigation of the response to the long-term radiation. Understanding of this response is essential for potential application of such materials as radioactive waste repository. Stability of the material subjected to irradiation is linked to the rate of the defect and structure instability formation. In general, ionic crystals are sensitive to ionizing radiation, thus $\beta$ radiation and heavy ion bombardment account for the most of observed defects due to their large penetration depths and high energy.

First systematic studies of naturally irradiated fluorite (so-called antozonite), $\mathrm{Ca}^{[8 c b]} \mathrm{F}_{2}^{[4]]}$ (C1 structure type with cation on $0,0,0$ site and anion on $1 / 4,1 / 4,1 / 4$ site, space group $F m \overline{3} m$ ) were performed by Asadi (1967a, b) and Berman (1956). Analyzing the bulk properties of the samples they found changes in specific weight and unitcell volume. They also noted qualitative discrepancies in diffraction peak profiles between irradiated and nonirradiated samples. More recently, dynamic processes of defect formation in $\mathrm{CaF}_{2}$ artificially irradiated by heavy ions were studied by mostly X-ray diffraction and TEM (e.g., Johnson and Chadderton 1980; Boccanfuso et al. 2001; Chadderton 2003). Chadderton (2003) showed that electron irradiation of $\mathrm{CaF}_{2}$ produced zero-valent $\mathrm{Ca}$ nanocrystals (forming superlattice in fluorite) and recombined fluorine following the equation: 


$$
\mathrm{CaF}_{2} \stackrel{\beta}{\longrightarrow} \mathrm{Ca}+\mathrm{F}_{2}
$$

Boccanfuso et al. (2001) described Ca colloids from fluorite bombarded by heavy-ions and they supposed extra reflections due to the superlattice formed by the colloids.

Recently Vlček et al. (2010) aimed to provide a very first insight into the nature of the defects induced by long-time irradiation in the nature. It was shown that the formation of the dislocation loops can be observed for low doses, but at higher doses the defect clusters developed instead.

Here we report analyses made on extended set of different samples and discuss possible variability of the fluorite structure response to irradiation. The principal goals include comparison of microstrains and domain sizes, study of unit-cell volume changes and characterization of the defects in the structure. To obtain the desired data the powder X-ray diffraction analysis (XRPD) was used. In addition, differential scanning calorimetry (DSC) was employed to assess the structure recovery processes. In order to evaluate possible influence of the chemical composition on the unit-cell size, the laser ablation inductively coupled plasma mass spectrometry (LA-ICP-MS) analyses were carried out.

\section{Samples and experimental methods}

\subsection{Sample description}

Several samples containing naturally irradiated fluorite were used in our study. Their characteristics are given in Table 1. Samples from Bratrství mine in Jáchymov
(Krušné hory Mts., Czech Republic), Kletno (Lower Silesia, Poland) and Zálesí (near Javorník, Silesia, Czech Republic) were exposed to irradiation by uraninite and their structure is presumably highly influenced by radiation. Fluorite is in direct contact with uraninite only in the samples Bratrství and Kletno 1. The sample from the Bratrství mine hosts an antozonite vein $(10 \mathrm{~mm}$ thick) surrounded by uraninite on both sides. Several measurements traversing the vein were carried out; they are marked A-E. All the samples mentioned above have a dim surface and dark purple color.

Fluorite samples from the Vlastějovice quarry were exposed probably to a lower dose, having been irradiated by K-feldspar and/or allanite. They do not exhibit dim surface and their color is lighter than that of materials irradiated by uraninite. In general, uraninite produces a large quantity of $\beta$ particles and causes homogeneous coloration of neighboring fluorite. On the contrary, activity of K-feldspar $\left({ }^{40} \mathrm{~K}\right)$ or allanite is much lower and consequently the coloring effect is not so marked: only the rim of the irradiated fluorite along the contact with the radioactive mineral displays purple coloring.

Standards used for comparison with irradiated samples included synthetic calcium fluoride Suprapur 99.95\% (Merck) and natural hydrothermal fluorite from Jílové mine near Děčín.

\subsection{X-ray powder diffraction (XRPD)}

Separated fluorite was ground for the XRPD measurements in acetone for about one minute. Fine-grained powders were dried and instantly measured. X-ray powder diffrac-

Tab. 1 Analyzed samples and methods of their study

\begin{tabular}{|c|c|c|c|c|c|c|}
\hline Name & $\begin{array}{l}\text { Locality / } \\
\text { source }\end{array}$ & $\begin{array}{l}\text { WGS } 84 \\
\text { coordinates }\end{array}$ & Radiation source & Mineralization type & Age & Methods and comments \\
\hline Bratrství A-E & $\begin{array}{l}\text { Jáchymov } \\
\text { (CZE) }\end{array}$ & $\begin{array}{l}50^{\circ} 22^{\prime} 19^{\prime \prime} \\
12^{\circ} 56^{\prime} 15^{\prime \prime}\end{array}$ & uraninite & $\begin{array}{l}\text { hydrothermal, carbonate veins with } \\
\mathrm{U}+\mathrm{Ag}, \mathrm{Bi}, \mathrm{Co}, \mathrm{Ni}, \mathrm{As}\end{array}$ & $\begin{array}{l}\text { Permian } \\
270 \mathrm{Ma}^{1)}\end{array}$ & $\begin{array}{l}\text { Several XRD measure- } \\
\text { ments on one sample, } \\
\text { LA-ICP-MS }\end{array}$ \\
\hline Kletno 1,2 & $\begin{array}{l}\text { Kletno } \\
\text { (POL) }\end{array}$ & $\begin{array}{l}50^{\circ} 14^{\prime} 49^{\prime \prime} \\
16^{\circ} 50^{\prime} 55^{\prime \prime}\end{array}$ & uraninite & $\begin{array}{l}\text { hydrothermal, quartz-fluorite-car- } \\
\text { bonate veins with } U+\text { selenides }\end{array}$ & Late Variscan? ${ }^{2)}$ & $\begin{array}{l}\text { XRD, DSC, } \\
\text { LA-ICP-MS }\end{array}$ \\
\hline Zálesí & $\begin{array}{l}\text { Zálesí } \\
\text { (CZE) }\end{array}$ & $\begin{array}{l}50^{\circ} 21^{\prime} 23^{\prime \prime} \\
16^{\circ} 57^{\prime} 09^{\prime \prime}\end{array}$ & uraninite & $\begin{array}{l}\text { hydrothermal, quartz-carbonate } \\
\text { veins with } \mathrm{U}+\mathrm{Cu}, \mathrm{Co}, \mathrm{Ni}, \mathrm{Bi}, \mathrm{Ag} \text {, } \\
\text { As, and } \mathrm{Se}\end{array}$ & $\begin{array}{l}\text { Mesozoic? } \\
161 \mathrm{Ma}^{3)}\end{array}$ & XRD, LA-ICP-MS \\
\hline Vlastějovice 1,2 & $\begin{array}{l}\text { Vlastějovice } \\
\text { (CZE) }\end{array}$ & $\begin{array}{l}49^{\circ} 44^{\prime} 07^{\prime \prime} \\
15^{\circ} 10^{\prime} 48^{\prime \prime}\end{array}$ & $\begin{array}{l}\text { K-feldspar, } \\
\text { allanite }\end{array}$ & $\begin{array}{l}\text { pegmatite, fluorite filling of the la- } \\
\text { te-pegmatite to early hydrothermal } \\
\text { stage }\end{array}$ & Variscan ${ }^{4}$ & XRD, LA-ICP-MS \\
\hline Jílové & $\begin{array}{l}\text { Jílové u Dě- } \\
\text { čína (CZE) }\end{array}$ & $\begin{array}{l}50^{\circ} 46^{\prime} 56^{\prime \prime} \\
14^{\circ} 06^{\prime} 21^{\prime \prime}\end{array}$ & none & $\begin{array}{l}\text { hydrothermal, fluorite veins in } \\
\text { Cenomanian sandstone }\end{array}$ & $\begin{array}{l}\text { Tertiary to } \\
\text { Quaternary }\end{array}$ & XRD \\
\hline Standard & Merck & - & none & - & - & $\mathrm{XRD}, \mathrm{DSC}$ \\
\hline
\end{tabular}

CZE - Czech Republic; POL - Poland; XRD - X-ray diffraction; DSC - Differential Scanning Calorimetry; LA-ICP-MS - laser-ablation inductively-coupled-plasma mass spectrometry

${ }^{1)}$ uraninite - isotope dating (Ondruš et al. 2003), ${ }^{2)}$ speculation of Banaś (1991), ${ }^{3)}$ uraninite - chemical dating (Fojt et al. 2005), ${ }^{4)}$ by analogy (Ackerman 2005), ${ }^{5)}$ Eger rift mineralization (Ulrych et al. 2007) 
tion patterns were collected with a PANalytical X'Pert Pro diffractometer (Institute of Geochemistry, Mineralogy and Mineral Resources, Faculty of Science, Charles University in Prague) equipped with an X'Celerator position-sensitive detector (PSD). Copper radiation was monochromatized with a secondary graphite monochromator. Data were stepscanned over the range between $10^{\circ}$ and $110^{\circ} 2 \Theta$ angle with $0.017^{\circ}$ step size and $300 \mathrm{~s}$ data acquisition time per entire position-sensitive-detector range, which corresponds to $2.4 \mathrm{~s}$ counting time per single step.

Diffraction analysis confirmed additional peaks of other phases in most of the samples studied, namely calcite and $\mathrm{K}$-feldspar; their contribution to the diffraction pattern can be, however, readily subtracted. The unit cell parameters were refined using software of Burnham (1962). The refinement employing Le-Bail fitting procedure as implemented in the HighScore Plus software (PANalytical; Almelo, The Netherlands) was applied to process the diffraction data in order to analyze crystallite size and micro-strain. Lanthanum hexaboride was used as an external standard to determine instrumental resolution function. The Williamson-Hall plot (Klug and Alexander 1974) is used to visualize the contributions of domainsize and micro-strain to peak broadening.

\subsection{Annealing}

The sample Kletno 2 was annealed to temperatures between 200 and $400^{\circ} \mathrm{C}$ in $50^{\circ} \mathrm{C}$ steps and from 400 to $700^{\circ} \mathrm{C}$ in $100^{\circ} \mathrm{C}$ steps. It took $30 \mathrm{~min}$ to reach individual temperature steps between $200{ }^{\circ} \mathrm{C}$ and $400^{\circ} \mathrm{C}$. For $\mathrm{T}>$ $400^{\circ} \mathrm{C}$ it took $45 \mathrm{~min}$ to reach the target temperature. Samples were heated for $3 \mathrm{~h}$ after reaching the desired temperature to overcome possible slow kinetics of the recovery process, then heating was stopped and the sample was let to cool down to the ambient temperature. Annealed $\mathrm{CaF}_{2}$ was then analyzed by XRPD.

\subsection{Laser ablation inductively coupled plasma mass spectrometry (LA-ICP- MS)}

The analytical work was performed on a quadrupolebased ICP-MS Thermo X Series II (Laboratories of the Geological Institutes, Faculty of Science, Charles University, Prague) coupled to a NewWave $213 \mathrm{~nm}$ laser microprobe. The sample introduction system and calibration and correction strategy closely followed those described by Strnad et al. (2009). NIST SRM 612 was used as an external standard for in situ analyses of fluorite. For internal standardization ${ }^{43} \mathrm{Ca}$ signals were applied. The quoted contents of minor and trace elements were calculated from multiple analyses based on the method by Rousseeuw and Verboven (2002).

\subsection{Differential scanning calorimetry (DSC)}

The sample Kletno 1 and Merck $\mathrm{CaF}_{2}$ standard were measured at the Laboratory of Thermal Analysis, Institute of Chemical Technology with a SETARAM DSC 131 (SETARAM Instrumentation; Caluire, France). Both samples of $8.7 \mathrm{mg}$ each were heated in air-atmosphere up to $500^{\circ} \mathrm{C}$ in a $\mathrm{Pt}$ cup. Changes in enthalpy were evaluated by Setsoft2000 software (also by SETARAM Instrumentation).

\section{Results and discussion}

Ewing et al (1987) described an increase in the unitcell volume as a common effect observed in all irradiated materials. Our study of naturally irradiated fluorite samples confirmed their general observations. The unitcell volumes of the synthetic standard corresponds to $V=162.59(9) \AA^{3}$ and that of the Jílové sample exhibits slightly increased volume of $V=162.65(9) \AA^{3}$. The sample from Vlastějovice influenced presumably by the lowest dose displays $0.15 \%$ unit-cell volume increase $\left(V=162.83(7) \AA^{3}\right)$ whereas the remaining samples that suffered more intense irradiation show a $0.26 \%$ increase (to $V=163.04(5) \AA^{3}$ ). This phenomenon is illustrated in Fig. 1 where a peak shift to lower diffraction angles for irradiated samples is shown. From the LA-ICP-MS analyses (Tab. 2) it is obvious that the concentrations of the substituting elements are too low to account for such an increase in the unit-cell volume, which we thus ascribe to irradiation. Moreover, the content of radioactive elements incorporated within the fluorite samples was found to be very low implying that the structure was irradiated from an external source.

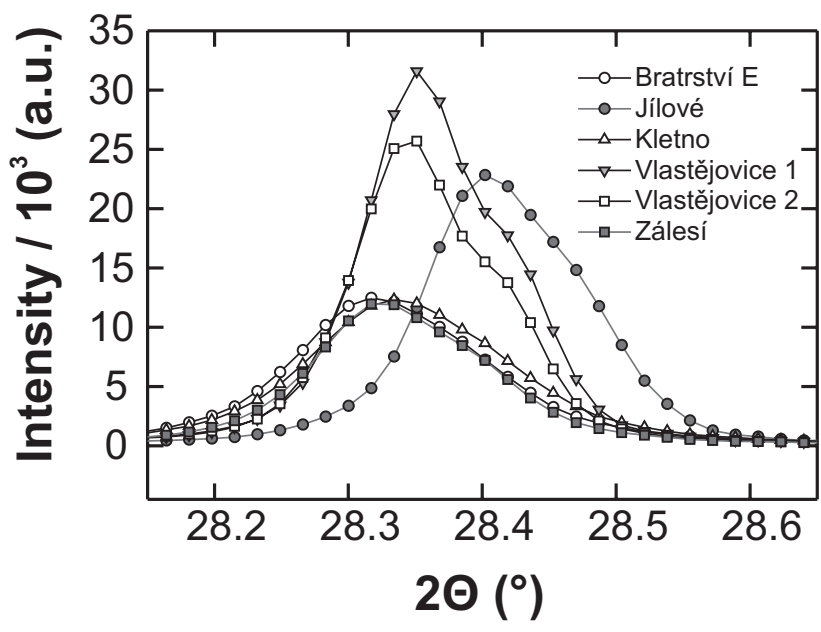

Fig. 1 Shifts in position of (111) peak in diffractograms of irradiated fluorites in comparison with natural non-irradiated sample from Jílové u Děčína. 
Tab. 2 Contents of trace elements (in ppm) in fluorite from localities Jáchymov, Kletno, Vlastějovice, and Zálesí

\begin{tabular}{|c|c|c|c|c|c|c|c|c|}
\hline & \multicolumn{2}{|c|}{ Jáchymov } & \multicolumn{2}{|c|}{ Kletno } & \multicolumn{2}{|c|}{ Vlastějovice } & \multicolumn{2}{|c|}{ Zálesí } \\
\hline & $\mu$ & $\sigma$ & $\mu$ & $\sigma$ & $\mu$ & $\sigma$ & $\mu$ & $\sigma$ \\
\hline $\mathrm{Mg}$ & 133 & 29 & 1.9 & 0.5 & 2.4 & 0.1 & 6 & 8 \\
\hline $\mathrm{Ba}$ & 0.56 & 0.07 & 0.09 & 0.02 & & & 0.17 & 0.04 \\
\hline $\mathrm{La}$ & 2.0 & 0.2 & 0.56 & 0.02 & 0.19 & 0.05 & 21 & 5 \\
\hline $\mathrm{Ce}$ & 1.7 & 0.2 & 1.2 & 0.0 & 0.5 & 0.0 & 25 & 6 \\
\hline $\operatorname{Pr}$ & 0.22 & 0.02 & 0.30 & 0.02 & 0.14 & 0.01 & 4 & 1 \\
\hline $\mathrm{Nd}$ & 0.94 & 0.10 & 2.0 & 0.1 & 1.02 & 0.03 & 16 & 5 \\
\hline $\mathrm{Sm}$ & 0.14 & 0.02 & 0.87 & 0.06 & 0.72 & 0.01 & 1.8 & 0.8 \\
\hline $\mathrm{Eu}$ & 0.032 & 0.007 & 0.23 & 0.02 & 0.098 & 0.002 & 0.3 & 0.2 \\
\hline $\mathrm{Gd}$ & 0.18 & 0.03 & 1.48 & 0.05 & 1.52 & 0.07 & 2.1 & 1.0 \\
\hline $\mathrm{Tb}$ & 0.023 & 0.004 & 0.27 & 0.02 & 0.38 & 0.02 & 0.2 & 0.1 \\
\hline Dy & 0.15 & 0.04 & 1.9 & 0.1 & 3.35 & 0.06 & 1.2 & 0.6 \\
\hline Ho & 0.03 & 0.01 & 0.43 & 0.02 & 0.85 & 0.02 & 0.3 & 0.2 \\
\hline $\mathrm{Er}$ & 0.09 & 0.02 & 1.14 & 0.07 & 2.76 & 0.05 & 0.8 & 0.4 \\
\hline $\mathrm{Tm}$ & 0.013 & 0.004 & 0.129 & 0.006 & 0.403 & 0.010 & 0.10 & 0.06 \\
\hline $\mathrm{Yb}$ & 0.08 & 0.02 & 0.65 & 0.05 & 2.65 & 0.09 & 0.7 & 0.4 \\
\hline $\mathrm{Lu}$ & 0.012 & 0.002 & 0.072 & 0.002 & 0.326 & 0.007 & 0.10 & 0.06 \\
\hline $\mathrm{Y}$ & 3.6 & 0.6 & 42 & 3 & 100 & 4 & 26 & 9 \\
\hline $\mathrm{Pb}$ & 8 & 3 & 0.06 & 0.01 & - & - & 6 & 6 \\
\hline $\mathrm{U}$ & 7 & 2 & 0.070 & 0.007 & 0.23 & 0.01 & 11 & 11 \\
\hline Th & 0.5 & 0.3 & 0.048 & 0.003 & 0.09 & 0.09 & & \\
\hline
\end{tabular}

Measures of position $(\mu)$ and scale $(\sigma)$ were calculated following procedures suggested by Rousseeuw and Verboven (2002) for small samples.

The change of unit-cell volume affects among other variables also the lattice potential energy. Its change can be estimated by measuring the change of the unit-cell volume, using the equation of Glasser and Jenkins (2000):

$$
U_{p o t}=A I\left(\frac{2 I}{V_{m}}\right)^{\frac{1}{3}},
$$

where $I$ denotes ionic strength, $A$ standard electrostatic conversion term and $V_{m}$ normalized molecular volume. Therefore the change of the lattice potential energy corresponds to:

$$
\Delta U_{p o t}=U_{p o t}\left[\left(\frac{V}{V_{0}}\right)^{\frac{1}{3}}-1\right],
$$

with the unit-cell volume of the irradiated fluorite and defect-free $\mathrm{CaF}_{2}$ denoted $V$ and $V_{0}$ respectively and the potential energy $U_{p o t}=2609$ $\mathrm{kJ} \cdot \mathrm{mol}^{-1}$ (Glasser and Jenkins 2000).

The irradiation-induced structure defects could be, in general, recovered by heating. The latent heat of the recovery process can be experimentally determined by DSC analysis and the structure stabilization energy release is expected as an exothermic peak. The DSC curve (Fig. 2) of the irradiated sample Kletno 1 was compared with the DSC curve of synthetic $\mathrm{CaF}_{2}$ standard and reveals a significant peak at $273{ }^{\circ} \mathrm{C}$, which corresponds to energy of $c$. $-16 \mathrm{~kJ} \cdot \mathrm{mol}^{-1}$. To the first approximation, change in the lattice potential energy and defect recovery contribute both to the energy release. The $\Delta U_{p o t}$ can be estimated through comparison of the unitcell volumes before and after the DSC experiment, corresponding to $V$ and $V_{0}$ respectively (Eq. 2). Observed decrease is $\sim 0.21 \%$ for the Kletno sample, providing a contribution of $c .-2 \mathrm{~kJ} \cdot \mathrm{mol}^{-1}$. Though the uncertainty in the curve integration limits makes the exact value questionable, the measured energy exceeds a simple change of lattice potential energy by almost an order of magnitude. This

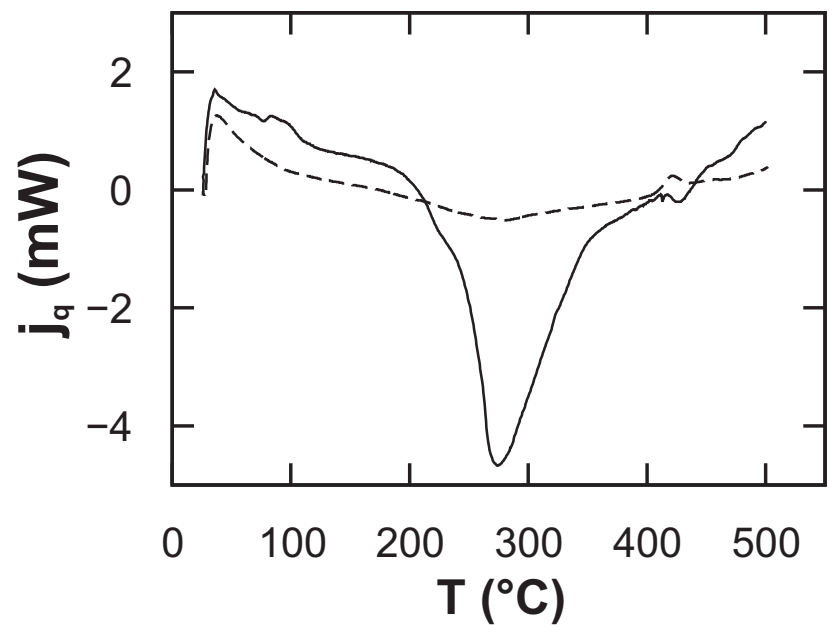

Fig. 2 The DSC curve of Kletno 1 sample (solid line) in comparison with standard sample (dashed line) with heat flow $j_{q}$ and temperature $T$. Exothermic peak at $273^{\circ} \mathrm{C}$ represents start of structure recovery process. 
indicates a relatively high abundance of structure defects (dislocations and other more complicated defects, e.g., defect clusters described in Yasunaga et al. 2006). The small peak shown on the DSC curve of $\mathrm{CaF}_{2}$ standard has c. $-2.8 \mathrm{~kJ} \cdot \mathrm{mol}^{-1}$ and may represent the natural defects causing thermoluminiscence, which is a common feature observed in fluorite.

Defects in the crystal structure observed by X-ray powder diffraction are manifested most obviously in two ways: by increase in Full Width at Half Maximum (FWHM) (shown in Fig. 3) and decrease in peak intensities. Magnitude of both phenomena is proportional to the expected received radiation dose and differs from one sample to another. The increasing amount of defects is proportional to the increase in micro-strain that was estimated by simplified Williamson-Hall approach obtained through full profile fitting, which, however, inherently assumes isotropic peak broadening. In highly irradiated fluorite samples from Bratrství, Kletno and Zálesí an average $0.13(3) \%$ micro-strain value was observed. The crystallite diameter is estimated to be $90(13) \mathrm{nm}$. Since the inferred strain is invariant in all samples exposed to irradiation, the value possibly represents the maximum strain that the fluorite structure could reach. This is in agreement with Chadderton (2003) who argued that there should be equilibrium between vacancies and recombined fluorine; when this equilibrium is reached no further damage is caused by ionization radiation. On the other hand, he supposed that the saturation would keep the number of defects low enough to prevent radiation-induced-straining of the material. This holds, however, for the weakly irradiated sample of Vlastějovice fluorite. The values of micro-strain found therein is comparable to that observed for both natural and synthetic standard samples which, in turn, indicates that even the fluorite that experienced no irradiation is strained to some degree.

It was previously shown in the literature that coloration of the irradiated fluorite is due to $F$-centres, $H$-centres or $V_{k}$-centres (Johnson and Chadderton 1980; Parker et al. 1981; Chadderton 2003). Our samples display color that varies from dark to light purple irrespective of the absorbed dose; it is thus obvious that the coloring is not merely associated with micro-strain.

Our results also demonstrate that there is only a negligible change among unit-cell volumes measured as a function of the distance from the radiation source; standard uncertainties exceed the differences making them statistically insignificant. Williamson-Hall analysis also reveals comparable micro-strain and crystallite size val-

Fig. 3 Increase of peak FWHM in diffraction pattern of an irradiated sample (Kletno 1) in comparison with standard sample. Peak position is standardized to have its maximum at $0.02 \Theta$ angle and intensity to have its maximum at 1 . Shown are (from top to bottom) peaks (111), (220), (400), and (422).

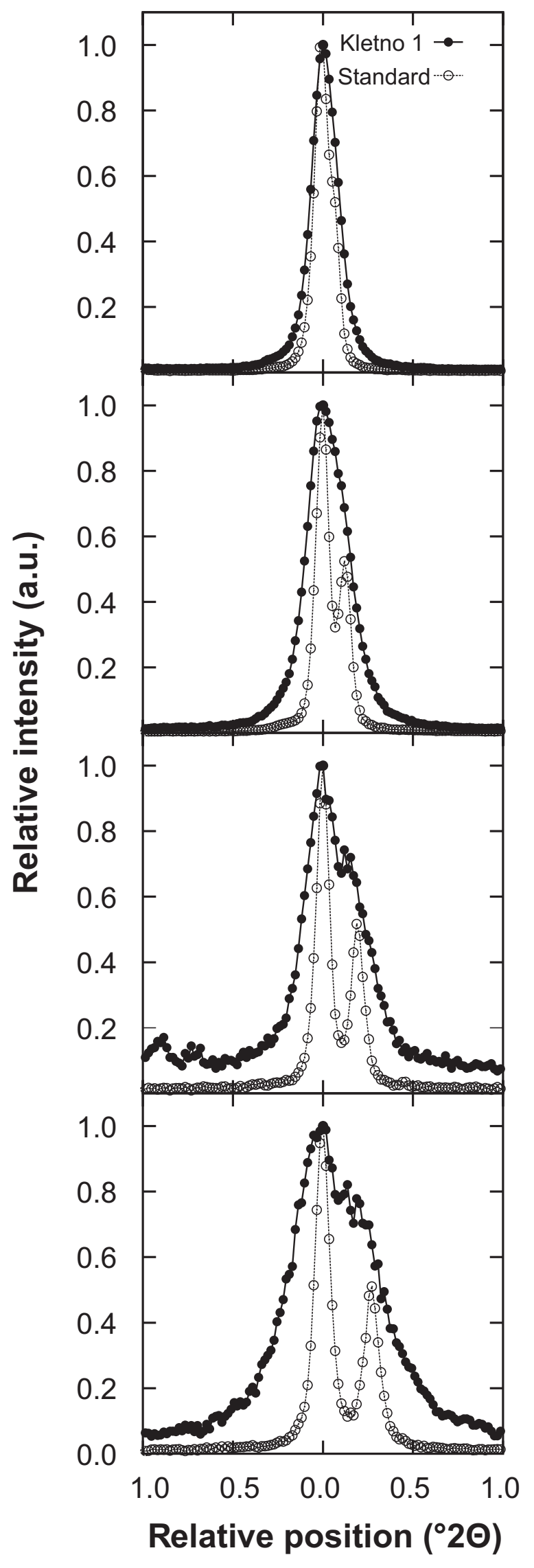


ues. These observations are consistent with very uniform distribution of structural defects and high penetration depths of the radiation.

Powder patterns of heated samples showed that the main structural recovery occurred at temperatures between 300 and $400^{\circ} \mathrm{C}$ when the minimum strain was reached. Further increase in temperature had no impact on the micro-strain and its value remained invariant, yet higher, than in non-irradiated calcium fluoride. This provides an independent proof that the color does not indicate strain rate since its change from purple to white (or colorless) observed at temperatures higher than $250^{\circ} \mathrm{C}$ was not related to any significant change of strain. This is consistent with the previous in situ experiments (Vlček et al. 2010) and confirms that the kinetics of the recovery process is very fast when the energy barrier is overcome and that the color is associated with point defects that do not influence the X-ray powder pattern.

Once peaks are fitted separately, including thus the effect of anisotropic broadening, the profile parameters do not display simple monotonous dependence of FWHM on the diffraction angle in contrast to the whole powder pattern fitting (Fig. 4). Consequently, modified Williamson-Hall method was used (Ungár 1998; Ungár et al. $1999,2001)$ in which a contrast factor is introduced for each individual diffraction $h k l$, correcting for the effect of anisotropic broadening. Parameter $q$, which is needed for contrast factor calculation and takes into account distinct influence of edge and screw dislocations, depends on elastic anisotropy $A_{i}=2 c_{44} /\left(c_{11}-c_{12}\right)$, with elastic constant of fluorite $c_{i j}$ taken from Ahrens (1995). Edge and screw dislocations have different values of $q$ parameter: $q^{\text {edge }}$ $\approx-1.02$ and $q^{\text {screw }} \approx-0.17$ (Ungár et al. 1999). Experi-

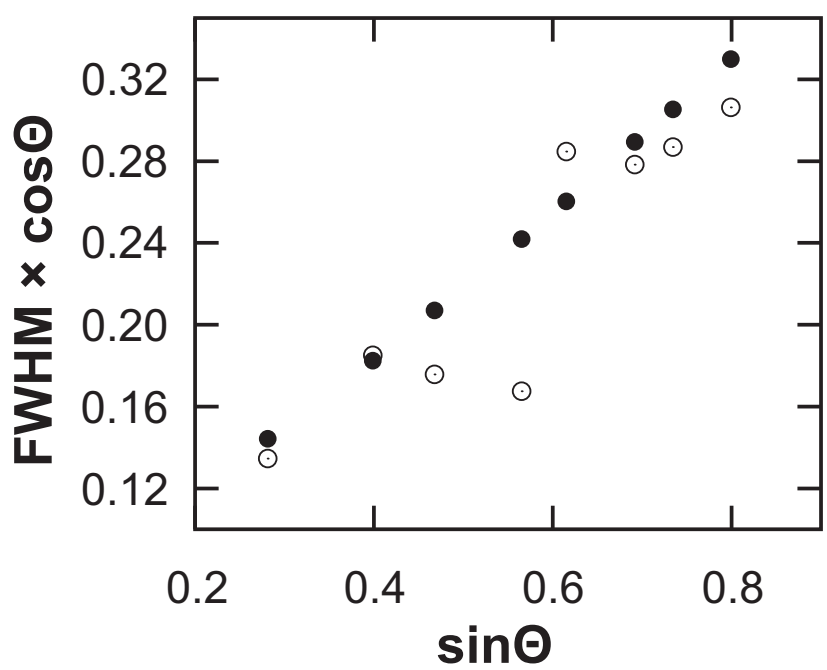

Fig. 4 Plot displaying the peak parameters from the whole powder pattern fitting (filled circles) and fitted individually for each diffraction peak accounting for the anisotropic broadening (open circles) for naturally irradiated sample Bratrství E. mental value, estimated using the procedure of Ungár et al. (1999) and Ungár and Tichy (1999), is $q^{\exp } \approx-0.92$. This value is questionable, though, since the experimental determination of $q$ parameter gives good results for materials with $A_{i} \geq 1$ because then $q>1$. In this case $q$ obtained through regression is inevitably more precise. The procedure of Ungár et al. (1999) and Ungár and Tichy (1999) was not found satisfactory and we tried to obtain the $q^{\text {exp }}$ value by fitting the parameter to obtain best linearization in modified Williamson-Hall plot. However, the $q^{\text {exp }}$ value obtained was out of expected range between $q^{\text {edge }}$ and $q^{\text {screw }}$. The model of strain broadening caused by dislocations was thus found inappropriate and, based on our previous results (Vlček et al. 2010), dislocations are thought to be less distinctive than other defects caused by irradiation. Therefore, presence of accumulations of the defects of the $1^{\text {st }}$ kind (eg. Kužel 2006), such as $F, H$, $V_{k}$ center clusters forming dislocation loops, is inferred, which is in agreement with our previous observations (Vlček et al. 2010).

We have already demonstrated for the Kletno sample that the positron life time spectroscopy reveals two component spectra (Vlček et al. 2010). First contribution comes from free positrons annihilating in a delocalized state in $\mathrm{CaF}_{2}$ lattice. The first-principles calculation, however, predicted this component to have slightly longer lifetime. This discrepancy is due to presence of openvolume defects, which trap positrons, as is described by a two-state simple trapping model (STM) (West 1979). These defects then give rise to a second component. They are attributed to clusters of defect centers and this was unambiguously confirmed by TEM. Taking into account the XRPD results we see that all the samples exhibit similar characteristics and the defect centers are therefore most probably the same in all highly irradiated fluorites.

The results above also have important implications for nuclear waste management. Although fluorite and $\mathrm{UO}_{2}$ (nuclear fuel) are isotypic, their response to irradiation differ significantly because of the effect of self-annealing observed in $\mathrm{UO}_{2}$ (Fayek et al. 2000). Fluorite appears obviously to be much more sensitive to irradiation than $\mathrm{UO}_{2}$ also because radiation damage to fluorite leads to formation of elemental $\mathrm{Ca}$ and $\mathrm{F}$ (Chadderton 2003), which are both aggressive species promoting possible structure deterioration. All the observations above make the use of fluorite as prospective containment of radioactive waste rather questionable.

\section{Conclusions}

Although the samples with uraninite as an external source of radiation received high radiation doses, none of them became metamict. Instead, changes in peak intensities 
and FWHM in powder patterns were observed. They correspond to an increase in the unit cell volume, which however never exceeds $0.26 \%$.

The results confirmed that the fluorite structure is damaged significantly due to irradiation and pointed out that the strains can be much higher than it was expected formerly. Moreover, they also supported the idea of strain saturation level, because the micro-strain values inferred from XRPD data were the same within experimental errors in all highly irradiated samples, even though each of them most probably received a different irradiation dose. No domain-size broadening was observed in any sample.

The structure recovery barrier is overcome at annealing temperatures between 300 and $400{ }^{\circ} \mathrm{C}$. The recovery processes were confirmed to be very fast. An exothermic peak on the DSC curve of irradiated fluorite indicates the onset of a recovery process. It starts at $273{ }^{\circ} \mathrm{C}$ and the observed enthalpy change corresponds to $\sim 200 \mathrm{~J} \cdot \mathrm{g}^{-1}$, which exceeds expected thermodynamic changes caused by increased unit-cell volume.

All these results are in very good agreement with previous data and show that the character of the defects is uniform, in spite of the fact that the samples were subjected to very high but unequal radiation doses and both the surrounding environment and their chemical composition vary. The formation of dislocation loops and the subsequent defect clustering is therefore assumed to be the major effect of irradiation influencing qualitatively the fluorite properties. Such behavior questions the use of fluorite as a prospective containment in the radioactive waste deposition.

Acknowledgements. The authors would like to acknowledge a valuable input from M. Dopita and an anonymous reviewer who substantially helped to improve the manuscript. This work was funded by the grant of the Ministry of Education of The Czech Republic No. MSM0021620855 (VV, RS, VG) Project No. MS 0021620834 (JČ) and Projects No. 106/07/0805 and AV KAN300100801 of the Czech Science Foundation (JD), and falls within the research plan AV0Z30130516 of the Institute of Geology AS CR (RS).

\section{References}

Ahrens TJ (1995) Mineral Physics and Crystallography: A Handbook of Physical Constants. American Geophysical Union, Washington, pp 1-354

ACKERMAN L (2005) Magmatic vs. hydrothermal origin of fluorites from Vlastějovice, Bohemian Massif. J Czech Geol Soc 50: 35-41

AsAdi P (1967a) X-ray topography in colored and uncolored zones of antozonite-fluorite. Phys Stat Sol 20: K71-K72
Asadi P (1967b) On the existence of piezoelectric textures in single crystals of antozonite-fluorite. Phys Stat Sol 20: K73-K75

BANAŚ M (1991) Pitchblende in Ag-Bi-Se paragenesis from Kletno deposit, Sudety Mountains, south-west Poland. In: Cuney M (ed) Primary Radioactive Minerals. Theophrastus Publications, Athens, pp 269-285

BERMAN R (1956) Some physical properties of naturally irradiated fluorite. Amer Miner 42: 191-203

Boccanfuso M, Benyagoub A, Toulemonde M, Trautmann C, Schwartz K, Dufour C (2001) Heavy-ion induced damage in fluorite nanopowder. Nucl Instr and Met in Phys Res B 175-177: 590-593

BuRnHAM CW (1962) Lattice constant refinement. Carnegie Inst Wash Yearbook 61: 131-135

CHADDERTON LT (2003) Nuclear tracks in solids: registration physics and the compound spike. Radiat Meas 36: 13-34

Ewing RC, Chaukomakos BC, Lumpkin GR, Murakami T (1987) The metamict state. MRS Bulletin May 16/June 15: 58-66

Fayek M, Burns P, Guo YX, Ewing RC (2000) Microstructures associated with uraninite alteration. J Nucl Mater 277: 204-210

Fojt B, Dolníček Z, Kopa D, Sulovský P, ŠKoda R (2005) Paragenesis of the uranium deposit at Zálesí near Javorník in Rychlebské hory Mts., Czech Republic. Acta Mus Silesiae (A) 54: 223-280 (in Czech)

Glasser L, Jenkins HDB (2000) Lattice energies and unit cell volumes of complex ionic solids. J Am Chem Soc 122: 632-638

Johnson E, CHADDERTON LT (1980) The void superlattice in fluorite. Micron II: 247-250

Klug HP, Alexander LE (1974) X-Ray Diffraction Procedures. Wiley, New York, pp 1-966

KuŽEL R (2006) Dislocation Line Broadening. In: KužEL R, Mittemeijer EJ, Welzel U (eds) Proceedings of EPDIC 9. Z Kristallogr Suppl 23: pp 75-80

Ondruš P, Veselovský F, Gabašová A, Drábek M, Dobeš P, Malý K, Hloušek J, Sejkora J (2003) Ore-forming processes and mineral parageneses of the Jáchymov ore district. J Czech Geol Soc 48: 157-192

Parker S, Song KS, Catlow CRA, Stoneham AM (1981) Geometry and charge distribution of $\mathrm{H}$ centres in the fluorite structure. J Phys C 14: 4009-4015

Rousseeuw PJ, Verboven S (2002) Robust estimation in very small samples. Comput Stat Data An 40: 741-758

Strnad L, Ettler V, Mihaljevič M, Hladil J, Chrastný V (2009) Determination of trace elements in calcite using solution and laser ablation ICP-MS: calibration to SRM NIST glass and USGS MACS carbonate and application to real landfill calcites. Geostand Geoanal Res 33: 347-355

UlRyCh J, AdAMOVIČ J, ŽÁK K, FrÁna J, ŘAnda Z, LANGRová A, Skála R, Chvátal M (2007) Cenozoic "radiobarite" 
occurrences in the Ohře (Eger) Rift, Bohemian Massif: mineralogical and geochemical revision. Chem Geol 67: 301-312

UNGÁR T (1997) Strain broadening caused by dislocation. ICDD Advances in X-ray Analysis 40: 612-673

UngÁr T, Tichy G (1999) The effect of dislocation contrast on X-ray line profiles in untextured polycrystals. Phys Stat Sol A 171: 425-434

Ungár T, Dragomir I, Révész Á, Borbély A (1999) The contrast factors of dislocations in cubic crystals: the dislocation model of strain anisotropy in practice. J Appl Cryst 32: 992-1002

Ungár T, Gubicza J, HanÁK P, Alexandrov I (2001) Densities and character of dislocations and size-distribution of subgrains in deformed metals by X-ray diffraction profile analysis. Mat Sci and Engin A319-321: 274-278

VlČEK V, ČížEK J, Drahokoupil J, Valenta J, Miyajima N, SKÁla R (2010) Defects in $\mathrm{CaF}_{2}$ caused by long-time irradiation and their response to annealing. Phil Mag 90: 2749-2769

West RN (1979) Positron Studies of Lattice Defects in Metals. In: Hautojärvi P (ed) Positrons in Solids. Topics in Current Physics 12, Springer, Heidelberg, pp 89-144 Yasunaga K, Yasuda K, Matsumura S, Sonoda T (2006) Nucleation and growth of defects clusters in $\mathrm{CeO}_{2}$ irradiated with electrons. Nucl Instr and Met in Phys Res B 250: 114-118 